\title{
A menoridade literária em Olívio Jekupé
}

Francis Mary Soares Correia da Rosa ${ }^{1}$

\section{O escritor Olívio Jekupé e suas trilhas ${ }^{2}$}

Pensar a menoridade na obra de Olívio Jekupé, tal como proposto neste artigo, é situá-la como contrassenso e contra discurso, não somente no campo literário, mas na expressão política de sua obra. Olívio Jekupé é um dos escritores indígenas de maior relevância no cenário nacional. Com uma carreira que se iniciou nos anos 1980, com publicações oriundas muitas vezes em feiras de poesias e jornais de circulação regional ou universitária, teve seu primeiro livro publicado de forma independente em 1999, com a obra 500 anos de angústia. Natural da cidade de Itacolomi, no Paraná, nasceu em 1965, filho de Donira da Silva (da etnia guarani) e de Olavio da Silva (natural da Bahia). Batizado de Olívio Zeferino da Silva, logo recebeu o "apelido" de "índio" devido a suas características físicas e à descendência por parte de mãe. Como o pai era motorista de caminhão, o jovem viveu parte de sua juventude em trânsito, até estabelecer um contato mais profundo com a situação dos indígenas por meio da aproximação com a avó materna e o contato com indígenas da etnia kaingáng, na cidade de São Sebastião de Amoreira, no Paraná (Lisbôa, 2015).

Esse contato foi responsável pelo conhecimento, por parte de Olívio Jekupé, da história e trajetória de uma personalidade indígena kaingáng cuja biografia é marcada por uma atividade política de luta pelos direitos dos povos indígenas, a saber, Ângelo Kretã. Nas palavras do próprio Jekupé, no livro Xerekó Arandu: a morte de Kretã (2002c), a divulgação da história e dos ideais de Kretã teriam o motivado a deixar Curitiba e partir para São Paulo, onde continuaria seus estudos universitários em Filosofia na Universidade de São Paulo (USP) - os quais tinha iniciado na PUC-PR. Foi em São Paulo, em 1991, que, vivendo na aldeia que hoje é conhecida

\footnotetext{
${ }^{1}$ Doutoranda em educação e contemporaneidade na Universidade Estadual da Bahia (Uneb) e professora da Universidade Estadual de Feira de Santana (UEFS), Feira de Santana, BA, Brasil. Email: francismrosa@hotmail.com

${ }^{2} \mathrm{O}$ presente artigo reproduz discussão apresentada anteriormente na dissertação de mestrado da autora, intitulada Tekoá: a literatura indígena e suas linhas de fuga (Rosa, 2016a).
} 
como Tenondé Porã, participou de um ritual de batismo e recebeu seu nome guarani, Tupã Jekupé (Lisbôa, 2015).

Com mais de doze publicações até o momento - incluindo publicações internacionais e em coletâneas -, o autor é considerado escritor infantojuvenil, contista e poeta. Jekupé estudou filosofia na Universidade de São Paulo (não concluiu) e dedica seus livros e palestras na luta pelos direitos indígenas.

Interessa-nos aqui, ao destacar de forma resumida a trajetória biográfica do autor, a demarcação de seu lócus enunciativo e do espaço de onde se origina seu discurso. Assumindo o nome de batismo guarani não só publicamente mas editorialmente, o autor anuncia sua filiação identitária e sua condição de indígena de forma recorrente em todas as suas publicações. Expressando nitidamente seu posicionamento social, o lugar da sua fala é demarcado pela identidade indígena guarani e por seu ativismo político. Seu nome de batismo no povo guarani, adverte o próprio autor, quer dizer mestiço (Jekupé, 2011a, p. 32). Isso expressa de forma contundente sua condição de estar na fronteira como viajante de dois mundos, a saber, do espaço da cidade, das instituições e a vida na aldeia (tekoá).

Contrariando uma perspectiva que associa o usufruto de elementos de outras culturas com a perda de sua própria ancestralidade, Olívio Jekupé demonstra em seus livros e em entrevistas que o uso da escrita segundo os moldes da escrita ocidental e o modelo de livro tradicional pode funcionar como uma arma e um elemento de afirmação cultural, assim como um enfrentamento político e ideológico.

Para Deleuze (1998), o objetivo da escrita é afirmar sua própria impessoalidade e por meio desta última, conjugar-se em fluxo a todos os devires-minoritários do mundo. Nesse aspecto, há determinadas literaturas que se apresentam como agenciamento, pluralizando linhas de fuga que promovem a criação desses devires, produzindo multiplicidades e efeitos, movimentando-se no seu devir. São como tocas, ${ }^{3}$ cheias de entradas. Seus personagens são sempre imagens de desterritorialização, criando fluxos e desfazendo significações.

Tal perspectiva nos coloca diante de uma escrita potencializada de devir e com caráter minoritário: uma literatura menor. Consagrado no

\footnotetext{
${ }^{3}$ Deleuze e Guattari usam o termo "toca" em Kafka-por uma literatura menor, para exemplificar as múltiplas entradas em uma obra literária rizomática.
} 
livro de Gilles Deleuze, Kafka: por uma literatura menor, escrito em conjunto com o psicanalista Felix Guattari, o termo remonta sua origem a obra do próprio Franz Kafka. Segundo Dirk Weissmann (2012), é ao falar sobre os escritos em língua iídiche na cidade de Praga que Kafka (1954) caracteriza e enaltece a presença destas "pequenas literaturas" (die kleinen Literaturen em alemão). É na tradução do diário de Kafka para a língua francesa, feita por Marthe Robert em 1950, que aparece pela primeira vez a expressão "petites littératures" já apontando, segundo Weissmann (2012), um tom valorativo na expressão utilizada pela tradutora ao oferecer aproximação de sentidos entre "klein", termo considerado apenas descritivo no alemão, e "petite", que possui um tom mais pejorativo no francês (Weissmann, 2013, p. 6). Para além de uma discussão sobre as origens, é necessário apontar que o conceito ganha um arranjo decisivo na obra de Gilles Deleuze e Felix Guattari, publicada pela primeira vez em 1975, Kafka: por uma literatura menor.

Essa obra foi responsável por popularizar o termo no meio acadêmico, ao mesmo tempo que evidencia seu poder de circulação e sua natureza subversiva, propondo uma inversão de natureza qualitativa na tradução de Marthe Robert: o menor (petite), outrotora de dimensão negativa, é transvalorado como algo desejável e portador de devir (Weissmann, 2013). Diante disso, construiremos um ponto de partida na obra deleuziana, porém seu ponto de contato será sempre como movimento aberrante imbricado a uma necessidade própria, nunca tentativa de reprodução. Isso significa que partimos do pressuposto que as categorias conceituais deleuze-guattarianas não serão simplesmente "aplicadas" ou "subsumidas" a obra de Olívio Jekupé. Deleuze e Guattari pensam a menoridade literária a partir da obra kafkaniana e produzem relações por meio desta. Experimentamos aqui os conceitos deleuze-guattarianos sem nos limitarmos ao que tais conceitos podem nos fazer pensar, mas indo além, movimentando-os, algumas vezes, como rupturas que traem os próprios conceitos e suas origens, possibilitando a própria criação conceitual.

\section{Por uma literatura menor}

Segundo Deleuze e Guattari (2002, p. 41): “As três características da literatura menor são a desterritorialização da língua, a ramificação do individual no imediato-político, agenciamento coletivo de enunciação". 
De acordo com os autores, a conceitualização de uma "literatura menor" não se restringe à produção escrita em uma língua dita "menor". A menoridade literária ocorre no desarranjo desterritorializante promovido pela construção no uso da língua que uma minoria faz em uma língua maior. Esse caráter desterritorializante lança a língua maior em processo de fuga, desterritorializando seus usos dentro dos ordenamentos discursivos (Rosa, 2016). O que pode um indígena ao escrever em português?

Nas obras de Olívio Jekupé, há um uso "desobediente" do chamado português formal. Sua escrita é marcada pela oralidade e o intercâmbio das palavras em guarani, como no livro Verá: o contador de histórias (2003a) e em um trecho de seus poemas na coletânea 500 anos de angústia (2015).

Um dia, Nhanderu, aquele que criou a yvy, encontrou um jurua que estava plantando avaxi e lhe perguntou:

- O que você está plantando? Como o homem viu que era um índio, não lhe deu nenhum valor e respondeu com ironia:

- Estou plantando cocô! (Jekupé, 2003, p.36).

Segundo Paulo V. Lisbôa (2015), tal pronunciamento e expressão da oralidade demarca uma das tradições culturais mais bem difundidas das culturas indígenas e, especificamente no caso de Olívio Jekupé, do povo guarani: a contação de histórias. ${ }^{4}$

Para Gabriela Chamorro (2008), entre os povos Guarani, a palavra não é somente sagrada, ela representa o núcleo que gera e possibilita a própria existência da vida. A palavra detém o poder de criar e transformar mundos, seres viventes e sentidos das coisas. A tradição oral na cultura guarani busca reinvestir o presente com o imaginário e o corpus cosmológico da tradição oral, mesclando passado e presente numa reorganização mítica com seu estatuto originário. Dessa forma, por meio da palavra, sagrada por excelência, o tempo retoma de forma circular alimentando o imaginário sempre com o aspecto do presente. Falar, de acordo com a autora, é decididamente sagrado para a tradição guarani. A tradição indígena guarani, tendo como expoente de análise a obra de Jekupé, textualiza a oralidade e lhe impõe uma configuração de continuidade e sacralidade: "coexistir na maleabilidade da língua, o novo com o antigo, a escrita com a

\footnotetext{
${ }^{4}$ Não se quer aqui dizer que somente sociedades indígenas se utilizam ou utilizaram da contação de histórias como recurso mnemônico, visto que tal recurso é comum a todas a civilizações humanas.
} 
oralidade, numa harmonia híbrida, mais ou menos imparável, que os textos literários nos deixam fruir" (Leite, 1998, p. 34).

Se as marcas da oralidade no processo de escrita não representam uma novidade no cenário literário nacional, por sua vez, no caso da tradição literária autoral indígena, elas nos permitem pensar em um recurso estratégico de aproximação e de estranhamento do leitor com a língua e com a própria cosmogonia guarani, de forma especifica nas narrativas de Olívio Jekupé.

Como sintetiza Olívio Jekupé (2009), a escrita do autor indígena tem uma marca essencial que é ser dirigida aos não índios. Essa forma de intenção e projeção da escrita revigora-se no desejo de oferecer uma contranarrativa ao estereótipo tão bem difundido na literatura romântica do "índio" homogêneo, exilado no passado.

Isso possibilita pensar que povoar a escrita com figuras de oralidade é também desvirtuar uma língua maior de seu uso ordenativo. A escrita surge não como representação tácita de um mundo gráfico, visto que mesmo a escrita em guarani é possibilitada mediante a estrutura do português hegemônico, mas como possibilidade da própria narrativa oral.

Dessa forma, sua aliança criativa ocorre com personagens que são frequentemente narradores, animais falantes, contadores de histórias, que destacam as tradições e se pronunciam como guardiões da memória e história do seu povo.

Certa vez, um índio estava ao redor da fogueira tomando chimarrão e contando histórias para crianças. Um ava'i (menino) de uns 12 anos pediu ao índio para contar a história do xapirê xii, o urubu-rei ou urubu-branco, como dizem os jurua kuery (Jekupé, 2013, p. 10).

O próprio autor se apresenta como narrador, como no caso da obra A mulher que virou Urutau: "Certa vez minha tia me contou uma história muito antiga. Ela disse que a tal história havia acontecido mesmo, e que sua mãe sempre a contava para os outros moradores da aldeia" (Jekupé, 2011b, p. 2).

A língua maior, o português, é desterritorializado no momento de seu uso, de sua expressão, nas reelaborações discursivas que se seguiram ao processo colonizador. Porém, a imposição da língua do colonizador não ocorreu de forma tácita, mas corroborou para construção de diversas maneiras de usos e na formulação de outras práticas sociais.

$\mathrm{O}$ uso de palavras em guarani mescladas ao texto em português demarca uma maneira "nativa" de falar o português nas obras de Jekupé. 
Não somente em uma nítida hibridização no idioma, mas em uma maneira que destoa da composição formal da escrita, não obedecendo concordâncias ou outros usos formais do português padrão.

- Está bem, vou ao yyakã apanhar uns picaretá para você - disse o marido, deixando-a muito feliz.

Ele pegou a melhor vara de pescar, algumas evo'i e foi para o yyakã. Depois de horas e horas, só tinha feito dar banho nas evo'i, pois peixe que era bom, nada! (Jekupé, 2003a, p. 28).

Para Leoné A. Barzotto (2012), as literaturas produzidas pelos grupos subalternizados das sociedades colonizadas caracterizam-se por ser contradiscursivas, refletirem a própria reelaboração da língua oficial em constante deslocamento e críticas ao modelo hegemônico de escrita. Essa língua "híbrida" não é somente a colagem descompromissada de palavras. Ao contrário, segundo a autora supracitada, essa escrita representa "um instrumento de luta, de sobrevivência e garantia de posteridade porque, com ela, o registro da história se faz possível" (Barzotto, 2012, p. 84). É na confrontação a uma estética de escrita dominante, desobedecendo aos paradigmas impostos da língua canônica, que seu uso permeia outro projeto de representação estética e cultural, que subverte a lógica logocêntrica, em meio a uma impossibilidade de escrever em outra língua, senão o português. Nesse estado de variação subversiva, em uma escrita que foge a um padrão normatizado, inclusive na forma de narrar e na organização lógica das histórias, está em jogo um processo radical de sublevação e reconquista. É muito comum, por exemplo, nas obras de Olívio Jekupé, leitores se "espantarem" com entradas/saídas de personagens, mudanças repentinas de "roteiro" e outras marcas que sugerem essa outridade lógica e referencial supracitada.

É o caso, por exemplo, do conto "A cobra e o cachorro", presente no livro de contos Verá: o contador de histórias (2003). A pequena história é narrada por Verá para seus amigos e descreve o encontro entre um cachorro e uma cobra. A cobra sentindo dor de cabeça, pede ajuda ao cachorro, que nutrindo uma raiva "ancestral" pelas cobras, lhe dá um conselho mortal: a orienta para que deite estirada no asfalto da rodovia. Como de costume, os indígenas que passam pelo local, matam a cobra a pauladas. Em outra ocasião, é narrado que o mesmo cachorro sente dores no estômago e, ao encontrar uma cobra (a "mulher" da cobra que foi iludida e terminou sendo morta na estrada), pede conselhos. O desfecho é 
inusitado e ressalta a outridade lógica que citamos: “- É só comer bastante capim - disse a cobra. O cachorro, então, comeu bastante capim e logo sarou da dor de barriga. Por isso, sempre que os cachorros têm dor de barriga vão correndo procurar capim para comer" (Jekupé, 2003a, p. 16).

A racionalidade monolítica ${ }^{5}$ consagrada na tradição ocidental, em que valores e maniqueísmos são parte fundante da composição narrativa, é colocada sob juízo radical na utilização de personagens que demarcam a alteridade ameríndia que se manifesta na cultura guarani. $\mathrm{Na}$ obra de Jekupé, é a perspectiva indígena que se coloca como primeira no processo de ordenação do mundo. É o próprio perspectivismo ameríndio, como tratado por Eduardo Viveiros de Castro (2015), que possibilita não considerarmos simplesmente como um artifício ao imaginário ou fantasioso (é por meio da presença de tais personagens que a maioria das obras são consideradas infantojuvenis) narrativas que apresentam, por exemplo, um urubu que é tão poderoso quanto um pajé ou performances que fogem ao roteiro tradicionalmente imposto aos animais: cães que falam; onças que viram pessoas e pessoas que viram astros do sistema solar. É a exemplificação da racionalidade plural presente no mundo que nos convida a questionar a consagração canônica de uma exclusividade e pretensa referência uníssona na maneira de ver a realidade que estabelece, entre outros aspectos, uma hierarquia nos valores que fatalmente impõem uma relação de dominação.

Diante disso, a radicalidade se configura no esforço de resistir como diferença irreconciliável tanto nos aspectos de uma política de escritura, tanto como na alteridade radical que visa romper o silenciamento dessas diferenças. Trata-se de uma apropriação qualificada e imbricada com o destronamento de uma cosmovisão monolítica. O uso do texto escrito na obra de Olívio Jekupé é a entrada, desautorizada, diga-se de passagem, no território do outro. Esse outro representa todas as esferas maiores, padronizadas e ordenativas da língua portuguesa, o mundo dos juruakuery. ${ }^{6}$ Esse processo de desterritorialização é nitidamente engajado na afirmação de sua identidade enquanto autor e no usufruto daquilo que anteriormente representava uma das formas de imposição cultural, a

\footnotetext{
${ }^{5}$ Não se quer aqui dizer que somente encontramos um determinado tipo de racionalidade na tradição ocidental, mas salientar que de uma forma geral, o imaginário ocidental canônico opera por dicotomias, maniqueísmos e pelo modelo de raciocínio oriundo da modernidade ocidental cartesiana.

${ }^{6}$ Juruakuery: não indígenas no idioma guarani (Jekupé, 2003, p. 45).
} 
saber, a língua portuguesa. Por meio disso, ocorre uma outra colonização, operada pelos sujeitos subalternizados, no usufruto da língua do colonizador. Deixando de ser um resto indesejado de uma violenta guerra, o uso desobediente e híbrido do português surge como usufruto político e de caráter afirmativo. Como ressalta o escritor angolano Manuel Rui Monteiro:

Não posso matar o meu texto com a arma do outro. Vou é minar a arma do outro com todos os elementos possíveis do meu texto. Invento outro texto. Interfiro, desescrevo para que conquiste a partir do instrumento escrita um texto escrito meu, da minha identidade (Monteiro, 1987, p. 309).

Nesse sentido, Olívio Jekupé apresenta uma dupla articulação do nomadismo que se exprime em sua própria condição de indígena, assim como no atestado de uma escrita marginalizada que não se assemelha à forma consagrada pela literatura ocidental.

Tal desdobramento do uso da língua por uma minoria subalternizada, conforme Deleuze e Guattari (2002), relaciona-se diretamente a seu imediato político. Isso significa possibilitar o entendimento de uma literatura menor como aquela que não se propõe a reprodução de questões de natureza estritamente individual, mas que emerge na proximidade política presente na própria arquitetura e funcionamento do texto. Nesse sentido, o próprio autor sofre processo de desterritorialização, e sua escrita não se refere somente a uma dada natureza na esfera do que é biográfico ou privado, mas em sua possibilidade de encontrar "seu próprio ponto de subdesenvolvimento, seu próprio patoá, seu próprio terceiro mundo, seu próprio deserto" (Deleuze e Guattari, 2002, p. 42). Tudo é político em uma literatura menor. E esse imediato político refere-se eminentemente ao enfrentamento e contestação de um estado de coisas ordenado e legitimado como hegemônico.

Nas obras de Olívio Jekupé, há indícios da natureza política e periférica em todas as suas personagens e nas relações que estas estabelecem com a comunidade dos juruakuery. Tal relação possibilita uma interpretação de enfrentamento nos níveis simbólicos das relações construídas. O caráter político se acentua no papel desagregador que a afirmação de sua indianidade provoca no imaginário coletivo de uma suposta identidade nacional homogênea. É o caso, por exemplo, da tekoa. Tekoa é palavra guarani que designa 
uma ideia de aldeia, comunidade que resguarda não somente o espaço físico, mas um espaço onde a indianidade e tradição ancestral dos povos indígenas é legitimada em todas as suas nuances.

Nas obras Tekoa: conhecendo uma aldeia indígena (2011) e Kamba'i: a ajuda do saci (2006), observamos uma narrativa que promove um enfrentamento a uma dada consciência coletiva que se propõe normativa, a saber, o modelo de cidadania monolítico presente no Estado brasileiro. No primeiro livro, a tekoa é uma comunidade indígena imaginada próxima à cidade de São Paulo e que é visitada por um garoto da cidade, de nome Carlos, cujo interesse principal é conhecer e aprender sobre a cultura indígena local. Ao longo da narrativa, Carlos percebe as diferenças e semelhanças entre sua cultura e a cultura indígena guarani, promovendo uma relação intercultural entre as personagens.

No segundo livro, a aldeia toma ares afirmativos por meio da presença da personagem ancestral Kamba'i. Por meio da história de Vera, um garotinho indígena que sonha em estudar na escola da cidade para aprender a "ler e a escrever na língua portuguesa", para poder "ajudar a defender seu povo" (Jekupé, 2006, p. 7), temos conhecimento da narrativa ancestral do Kamba'i, o protetor da floresta e dos animais. O Kamba' $i^{7}$ ou Saci é retratado como personagem indígena e distinto da visão preconizada nas narrativas de Monteiro Lobato, a saber, um garotinho negro e muito travesso, sem uma das pernas. A grande aparição de Kamba'i na narrativa ocorre diante de um trágico acidente que deixa o garotinho indígena Vera paralítico. Sem ajuda dos médicos da cidade, Vera retorna à aldeia, e seu pai, Karai, pede ajuda ao ser ancestral:

Quando escureceu, Karai comeu um pouco da caça que sua mulher preparou, depois pegou seu petygua, colocou pety e saiu para mata. [...] Andou horas e horas pela mata, gritando o nome de Kamba'i.

- Kamba"iiiiiiiiii! Meu filho precisa de sua ajuda. Apareeeeeça! gritou tanto que até os animais se assustaram. E continuou:

- Grande protetor dos animais e da floresta, se estiver me ouvindo, apreeeeeeeça! (Jekupé, 2006, p. 26).

\footnotetext{
${ }^{7}$ Em guarani, segundo Olívio Jekupé, a palavra Saci origina-se da narrativa do Jaxi Jatere ou Kamba'i e diferencia-se da versão e caracterização feita pelas obras de Monteiro Lobato e do imaginário nacional. Disponível em: 〈https://goo.gl/MEUTDw〉. Acesso em: 2 ago. 2013.
} 
Os gritos surgem como intensivos, mostrando a própria vazão de conflito do interior da língua, conotando a dor e o desespero pela busca ancestral. Segundo Deleuze e Guattari (2002, p. 48), uma literatura menor promove esse tipo de aparição na língua e os intensivos se constituem como "qualquer utensílio linguístico que permite propender para o limite de uma noção ou de ultrapassá-la". Nesse momento, Kamba'i vai ao encontro da personagem Vera, que ao ver o Kamba'i redescobre sua fé nas narrativas ancestrais. Percebe-se nitidamente o tom de empoderamento do texto, pois é por meio da crença no sagrado ancestral indígena que a personagem Vera volta a andar. Ou seja, em desacordo com a imagem da indianidade estereotipada que representa o indígena como espectro de um passado heroico, mas inconciliável com o presente, Olívio Jekupé insiste em uma linha que repercute no próprio projeto indígena de autoderminação, pois a crença na ancestralidade e no sagrado guarani atuam como o fortalecimento e defesa da própria indianidade, menos branca e vinculada a tudo que foi e é renegado, aos rastros deixados na história por todos os bestializados.

Em outro livro intitulado O Saci verdadeiro (Jekupé, 2002b), o Kamba'i retorna como personagem em dois contos que remetem à ancestralidade e à natureza afirmativa de sua obra. No primeiro, intitulado "O índio de um só braço", o Kamba'i aparece para ajudar um indiozinho que se sentia triste e incapaz por não ter um braço, agraciando-o com um braço invisível, que somente ele, por ser bom e acreditar no Kamba'i poderia ver. No segundo conto, que dá nome a obra, O Saci verdadeiro, o Kamba'i retorna para provar para um indiozinho, de nome Karai e que frequenta a escola citadina, que o verdadeiro Saci (ou Kamba'i) não se apresenta tal como descrito nos contos de Monteiro Lobato, mas, sim, como condizente com as histórias narradas por sua mãe. Observe o diálogo entre Karai e sua mãe:

- Sabe a professora, ontem, falou sobre o Saci-Pererê.

- Sobre o Saci?

- Sim, sobre ele, só que achei estranho. Sua mãe foi logo dizendo:

- Não falou sobre o nosso Saci, o verdadeiro, e sim sobre aquele Saci negrinho que eles inventaram.

- Eu já ouvi alguns índios dizendo que os brancos falam muito do Saci, este que eles criaram. Na verdade, não entendo por que eles criaram esta história, usando nosso Saci e transformando tudo ao contrário (Jekupé, 2002b, p. 31). 
Tal posicionamento no arco de histórias mencionado remonta à constituição de imagens cobertas com o imediato político, típico de uma menoridade literária. Isso ocorre pela presença de uma discussão latente em que está em jogo todo um conjunto de dispositivos institucionais, culturais e estatais que deslegitimam os saberes ancestrais como a ausência de uma escola indígena na aldeia, ou mesmo, uma escola citadina sem o status intercultural que reproduz uma imagem estereotipada dos indígenas. Segundo Graça Graúna (2013), a própria descrição da personagem "Saci" pela professora nos moldes das histórias de Monteiro Lobato ocorre em uma correspondência a visão negativa atribuída também aos negros e negras na sociedade brasileira.

Nos três livros, a tekoa apresenta-se como "guardiã" ancestral de um multiverso polissêmico em que se fala guarani, em que os espíritos da floresta se apresentam novamente aos humanos, e os animais falam que ser indígena não é motivo de discriminação. Frente a uma realidade de um contato quase que inevitável com o universo dos Jurua, concretizando a diáspora indígena ${ }^{8}$ aos ambientes fora do contexto da aldeia.

Como dispositivo polissêmico, na obra de Jekupé, a tekoa não é um mero espaço ou cenário onde se desenvolve a trama. Ela reelabora e ressignifica a experiência política diaspórica indígena. Configurada nas trilhas da cidade dos brancos, porém com seus próprios códigos e normas, a tekoa se apresenta, assim, experienciada como personagem e máquina de guerra em uma existência minoritária.

Para Gilles Deleuze e Felix Guattari (2012), uma máquina de guerra revela-se como plano exterior a todo o aparelho estatal. Isso significa dizer que, para os autores supracitados, a máquina de guerra se apresenta como exterioridade no limite irremediável de sua própria filiação ou proximidade com a forma-Estado. Não é uma exterioridade absoluta, apresentando-se mais como uma concorrência em coexistência. A máquina de guerra é fundamentalmente um dispositivo de experimentação, ao nível da criação, que se situa às margens de toda e qualquer estrutura estática do campo social. Seu objetivo não é propriamente a guerra, mas fazer fugir um dado campo estratificado.

A forma-Estado, como forma de interioridade, tem uma tendência a reproduzir-se, idêntica a si através de suas variações, facilmente

\footnotetext{
${ }^{8}$ Para Graça Graúna (2013), a diáspora indígena existe desde os tempos da invasão portuguesa, que obriga e normatiza na sociedade que aqui se configurou, uma desterritorialização cultural, política e geográfica dos povos indígenas.
} 
reconhecível nos limites de seus polos, buscando sempre o reconhecimento público (o Estado não se oculta). Mas a forma de exterioridade da máquina de guerra faz com que esta só exista nas suas próprias metamorfoses; ela existe tanto numa inovação industrial como numa invenção tecnológica, num circuito comercial, numa criação religiosa, em todos esses fluxos e correntes que não se deixam apropriar pelos Estados senão secundariamente (Deleuze e Guattari, 2012, p. 25).

Nesse aspecto, a tekoa, tal como caracterizada na obra de Olívio Jekupé, não é somente espaço desterritorializado do Estado, promovendo a pulsão da existência e cosmovisão indígena. Ela se conecta a tantas outras máquinas fugidias, como a própria literatura do autor (as literaturas indígenas em geral), como a língua, como a educação indígena, como todas as menoridades do mundo. A pergunta é fundamental: o que significa a aldeia indígena, todas as aldeias do mundo frente a máquina institucionalizante e orquestrada do Estado? Sociedades contra o Estado. A tekoa, personagem e máquina de guerra, experimenta-se como o fora do próprio Estado organizado. É espaço de resistência, "sem lei e sem rei", onde os dispositivos da esfera estatal encontram-se desarticulados pela desobediência ao imperativo subliminarmente proposto na maioria das políticas indigenistas, a saber, a desarticulação da identidade indígena por meio da assimilação de uma cidadania monolítica, uma cultura nacional homogeneizante e o secular despejo linguístico. Nesse último aspecto, referimo-nos ao ordenamento de imposições linguísticas e culturais desde o período colonial, que deslocam para a marginalidade e o discurso de desaparecimento às línguas indígenas.

$\mathrm{Na}$ tekoa, os indígenas resistem e sobrevivem ao desafio de serem invisibilizados ou lidos como uma "minoria" dispensável aos projetos de modernidade e a lógica da organização social, cultural e econômica dominante. Para Osmar Moreira (2002, p. 175), a constituição de uma máquina de guerra é uma investida que incorre numa atitude de crítica diante, entre outras coisas, de toda e qualquer "noção de cultura que se quer hegemônica", projetando um estado de devir na própria subjetividade dos sujeitos envolvidos.

A tekoa é assim experimentada, sonhada, virtualizada por Olívio Jekupé, não somente como espaço de territorialização da indianidade híbrida, visto que seus personagens Vera (Kamba'i: a ajuda do Saci), Karai 
(O Saci verdadeiro) e próprio Olívio Jekupé (em Xerekó Arandu: a morte de Kretâ) experimentam a desterritorialização da indianidade na cidade e seu modo de vida, retornando à aldeia em um movimento que alude à própria relação de interculturalidade presente no projeto de indianidade do autor. Observe-se a descrição da experiência comparada vivida pelo personagem Carlos, que sai da cidade de São Paulo para visitar a aldeia, no livro Tekoa: conhecendo uma aldeia indígena:

Vinte dias se passaram. [...] Aprendi a acender uma fogueira, fritar paková verde, assar pão na brasa, usar arco e flecha, fazer armadilhas para caçar animais e apanhar aves, identificar espécies de árvores que fornecem remédios. Percebi que tal conhecimento jamais me abandonaria, porque tinha se convertido em sabedoria. Voltar para a agitação de São Paulo. Reencontrar o cheiro da fumaça, os sujos rios Tietê e Pinheiros, a gritaria das pessoas, o barulho dos carros, máquinas, indústrias, sirenes e celulares. A realidade onde nasci e cresci me pareceu muito distante da aldeia. [...] Aquele que se julga superior, na realidade, não sabe o lugar que ocupa no mundo (Jekupé, 2011, p. 26-27).

A tekoa se apresenta como criadora de diferença, máquina de guerra destruidora por excelência, promotora de agenciamentos e de multiplicidades. $\mathrm{O}$ agenciamento é uma expressão da multiplicidade e efetuação do desejo, de caráter heterogêneo e que se apresenta por meio das relações possíveis entre termos de naturezas distintas (Deleuze e Parnet, 1998, p. 83). Para além das configurações das relações de força que compõem o campo social, o agenciamento é inserção de uma irregularidade disjuntiva nos alicerces do poder.

Nesse sentido, ao destacarem que a terceira característica principal de uma menoridade literária se constitui na sua composição como valor coletivo, Deleuze e Guattari (2002), propõem que o campo político seja a força criativa de todo o enunciado. Isso significa dizer que o "enunciado individual é imediatamente coletivo, e o escritor, na sua individualidade, desde já articula uma ação comum" (Schøllhammer, 2001, p. 63). Se o agenciamento demonstra um caráter individualizante, segundo François Zourabichvili (2009), não é nunca no sentido de pertencer a um sujeito em exclusividade. Mas, na relação que ocorre entre o devir singular de alguém e em seu agenciamento maquínico para uma coletividade,

há uma figura universal da consciência minoritária, como devir de todo o mundo, e é esse devir que é criação. Não é adquirindo 
a maioria que se o alcança. Essa figura é precisamente a variação contínua, como uma amplitude que não cessa de transpor, por excesso e por falta, o limiar representativo do padrão majoritário. Erigindo a figura de uma consciência universal minoritária, dirigimo-nos a potências de devir que pertencem a um outro domínio, que não o do Poder e o da Dominação. É a variação contínua que constitui o devir minoritário de todo o mundo, por oposição ao Fato majoritário de Ninguém (Deleuze e Guattari, 1995, p. 57).

O viés coletivo, como destacado pelos filósofos franceses, perpassa então pelo desaparecimento do autor, naquilo que sua autoria destoa de tudo que é posto como qualidade do "autoral", pois uma tal menoridade literária deve sobretudo agenciar outras vozes e por elas ser atravessada.

Olívio Jekupé, em toda sua obra, não escreve somente sobre o despejo territorial, o preconceito e o enfrentamento político de sua própria história. Mas, por meio de sua voz, promove o agenciamento coletivo de outras vozes indígenas despejadas política, econômica e culturalmente. Em um dos seus poemas, no livro 500 anos de angústia, escreve:

Nosso povo, cada vez mais está

Sendo perseguido e morto

O governo continua sentado

Em seu trono e, como sempre,

Não faz nada.

Como fico nervoso em

Saber que os verdadeiros

Brasileiros e donos de

Todas estas terras são

Tão marginalizados assim.

Desgraça. Falam tanto

Que o Brasil é o país

Mais católico e cristão

Do mundo, só que

Nosso povo continua sofrendo (Jekupé, 2015, p. 44).

Em outro texto publicado na revista Leetra Indígena, Jekupé enfatiza a conexão com a coletividade de sua obra: "eu sofri muito por não ser entendido, e hoje muitos me valorizam e juntos valorizam nosso povo indígena; é que a sociedade é complexa, se um índio faz uma coisa 
errada, eles dizem que os índios são assim, por isso, quando valorizam um índio escritor, aí valorizam todos os índios" (Jekupé, 2012, p. 34-35).

O autor Jekupé não só reflete e recria sua indianidade ao afirmar seu vínculo com o povo Guarani por meio das narrativas ancestrais, da memória ou mesmo das histórias majoritariamente imaginadas. Ele promove a construção de um plano de sentido, pleno de agenciamentos sígnicos, maquinando a invenção de um povo, forjando uma coletividade pan-indígena.

Para Gilles Deleuze (2011), a tarefa da literatura é escrever um povo que falta. "Não se escreve com as próprias lembranças, a menos que delas se faça a origem ou a destinação coletivas de um povo por vir ainda enterrado em suas traições e renegações" (Deleuze, 2011, p. 14). O devirminoritário é fundamentalmente político e, nesse sentido como salienta David Lapoujade (2015), constitui-se como verdadeira máquina de guerra do por vir. Isso implica dizer que se está na seara da criação de direitos, pois todo devir-minoritário é invisível e inaudível. Até que se grite!

Essa composição e esfera do porvir na questão do direito possibilita compreender que se está modificando a percepção sobre a própria potência da lei. A justiça é desejo (Deleuze, 2002, p. 89), e isso reelabora a própria expectativa sobre o direito, a saber, que ele não existe como aparelho que legitima o que existe, mas que opera em "fazer existir o que não tem legitimidade, o que ninguém vê nem ouve, em tomar o partido das multiplicidades imperceptíveis" (Lapoujade, 2015, p. 275).

Desse modo, como propõe Schøllhammer (2001, p. 64), “o aspecto imediatamente político da literatura menor não tem nada a ver com seu conteúdo ideológico, mas com sua performance enquanto uma multiplicidade de atos de fala que forma uma máquina expressiva". Assim, o texto literário, as literaturas dissidentes em meio a uma literatura que "se chama grande" (Deleuze e Guattari, 2002, p. 42) operam na promoção da audição de outros logos, em um limite, como afirma Deleuze (2011, p. 9), que "arrasta a língua para fora de seus sulcos costumeiros, leva-a a delirar".

Isso se reflete na própria presença de uma outridade na qual as comunidades indígenas podem ser posicionadas. Uma outridade que, segundo Benedito Nunes (2011), coloca os povos nativos não somente como diferença, mas também como expoentes "bárbaros", tal como na visão dos gregos, como estranhos e opostos inegociáveis frente à cultura majoritária. 
No caso dos indígenas no Brasil, aqueles que preenchem o indexical "eu" na dicotomia eu-outro são os brasileiros que, nas vicissitudes históricas que se passaram neste chão, mais se adaptaram ao modo de ser ocidental abrasileirado - o povo em que baixou o espírito transatlântico civilizador. Sob o ponto de vista de grande parte dos brasileiros ocidentais, ou seja, dos "civilizados", seja classe baixa ou alta, seja governo ou povo, os indígenas aparecem como o completamente outro, aquilo com o qual nada ou pouco se compartilha. Inclusive a nacionalidade, já que não parece serem brasileiros - são estrangeiros conterrâneos (Costa, 2015, p. 152).

Uma outridade assim radical coloca-nons diante da possibilidade de pensar que tais características se submetam a uma aproximação na composição de uma animalidade, pensada como devir-animal.

\section{Devir-menor e devir-animal e devir-onça...}

O devir-animal é experimentado em Deleuze e Guattari (2002) não somente como alteridade radical ao modelo de que se apresenta como majoritário, sejam as formas maiores de sociedade (Estado), na composição das identidades (Homem-branco) e nas cosmovisões (a Ocidental, por exemplo). O devir-mulher, devir-criança e o deviranimal, defendem Deleuze e Guattari (2002, p. 34), são componentes de desterritorialização que estão em continuo movimento e que promovem linhas de fuga e intensidades "em benefício de uma matéria não formada, de fluxos desterritorializados, de signos a-significantes". Dessa forma, ultrapassam a simples imitação, do jogo territorializante "de algo" a imitar um animal. Simples reprodução! O que está em jogo em um devir-animal é a conjunção de fluxos, relação de devires e captura: a desterritorialização absoluta do homem.

Um devir não é uma correspondência de relações. Mas tampouco é ele uma semelhança, uma imitação e, em última instância, uma identificação. [...] Os devires-animais não são sonhos nem fantasmas. Eles são perfeitamente reais. Mas de que realidade se trata? Pois se o devir-animal não consiste em se fazer de animal ou imitá-lo, é evidente também que o homem não se torna "realmente" animal, como tampouco o animal se torna "realmente" outra coisa. O devir não produz outra coisa senão ele próprio. É uma falsa alternativa que nos faz dizer: ou imitamos, ou somos. O que é real é o próprio devir, o bloco de devir, e não os termos supostamente fixos pelos quais 
passaria aquele que se torna. $\mathrm{O}$ devir pode e deve ser qualificado como devir-animal sem ter um termo que seria o animal que se tornou (Deleuze e Guattari, 1997, p. 18).

Por meio disso, o componente devir-animal não busca modelos de identificação com pretensas fórmulas simbólicas, arquetípicas ou que primam pela representação. Para Deleuze e Guattari (1997), haveriam três espécies ou formas de se agenciar um animal: há animais individuados, familiares, domésticos; há os de segundo tipo, os que são de classificação ou Estado; e, por fim, os animais demoníacos, de matilhas, que fazem devir. O devir-animal é sobretudo entendido na esfera da relação. A pergunta fundamental é o que devém isso? Com que conjunto de séries proliferam? Sua recusa está em se submeter a qualquer representação do familiar, do acoplamento com a máquina estatal. $\mathrm{O}$ devir-animal se manifesta nas matilhas. Segundo Viveiros de Castro (2007, p. 116): “Nem metáfora, nem metamorfose, um devir é um movimento que desterritorializa ambos os termos da relação que ele estabelece, extraindoos das relações que os definiam anteriormente para associá-los através de uma nova 'conexão parcial'". Experimentando a teoria deleuziana por essa entrada, um dos contos de Jekupé nos oferece possibilidades de diálogo com os aspectos supracitados.

Os animais, sagrados e não sagrados são criaturas recorrentes na obra de Jekupé. Para nosso estudo serão especificamente desenvolvidos diálogos sobre o conto "Ava'i que virou xivi", presente no livro Arandu Ymanguaré (2003b). A palavra xivi em guarani que dizer onça, e ava'i quer dizer menino. $\mathrm{O}$ conto rápido narra a história de uma criança que se transforma em onça durante a noite e sai para caçar. As saídas noturnas causam suspeita em sua mãe, que numa noite, resolve fingir que adormecia para ver o que ocorria com o filho, que mesmo sendo amamentado, sempre estava com fome:

Nisso o pequeno ava'i se levantou e saiu pra fora e aconteceu algo: ele virou xivi e em seguida foi caçar. Sua mãe, vendo aquilo, ficou com medo e muito assustada mas foi dormir, fazendo de conta que nada tinha acontecido. Já o xivi, quando comeu bastante, virou outra vez o que era e voltou para casa, deitou e puxou o peito da mãe para mamar, mas ela fingia que dormia - e bem assustada, por saber que tinha um filho que virava xivi (Jekupé, 2003b, p. 16, grifo nosso). 
A descrição sobre a condição da personagem que se transforma em xivi é interessante, pois, da forma que é apresentado no texto, não ocorre uma delimitação sobre a condição da criança: o trecho "virou outra vez o que era" demarca o espaço heterogêneo, indefinido e relacional entre ambos os seres. Tanto xivi ou o ava'i não são uma coisa que passa a ser outra, mas estabelecem relações, um com o devir do outro. Não é um menino que se transforma em onça, e nem uma onça que se transforma em menino. A frase "virou outra vez o que era" presente no trecho, coloca o devir-onça (devir-xivi) em uma condição de entrelaçamento rizomático entre dois mundos heterogêneos. É exatamente essa característica apontada por Deleuze. O devir-animal "é sempre de uma ordem outra que a da filiação. Ele é da ordem da aliança” (Deleuze e Guattari, 1997, p. 19).

O devir-onça é uma condição imprescindível para que se efetue a condição do devir-animal em matilha. O devir-onça é apresentado em toda sua potência de animal feroz, selvagem e indomesticável. Sua ferocidade é tamanha que causa medo e angústia de uma morte imediata. A mãe do menino manifesta o temor: "Enquanto eles conversavam, o ava'i estava em casa com sua mãe, que estava com medo porque vai que ele vire xivi: ela tinha medo de ser comida pelo próprio filho" (Jekupé, 2003b, p. 20).

É por meio da condição de matilha que ocorre o agenciamento coletivo de enunciação. O devir-onça agencia a floresta, a literatura de Jekupé e a própria alteridade radical de ser indígena. Trata-se não de um devir-onça, mas devir-onça. Presente como imagem de tudo que escapa aos blocos territorializantes do Estado, do familiar e do domesticável, devir-onça é uma força diabólica do porvir. A potência não se apresenta necessariamente na transubstanciação no felino, pois no momento em que o ava'i se transfigura em xivi, não há nem ava'i (humano) e nem xivi (onça). Pode-se citar a própria ausência das "falas" ou "urros" do felino no embate final com os indígenas da aldeia como a imagem da própria falência da linguagem, "que deixa de ser representativa para tender para os extremos ou limites" (Deleuze e Guattari, 2002, p. 49).

Demorou mais de uma hora a andança pela mata mas, de repente, um dos grupos viu o xivi. Estava ao lado de uma árvore comendo sua caça. Nisso os índios foram vistos pelo xivi que deixou o que comia de lado e foi logo mata-los, só que não deu tempo. É que um dos índios já estava preparado com seu arco e flecha (Jekupé, 2003, p. 20). 
O silêncio que a acompanha o epílogo do conto é a própria língua impelida ao seu limite. Nem o xivi nem o ava'i falam ou emitem qualquer som. O silêncio, incomunicável no texto não é falta, mas o local da intensidade da língua, de seu limite.

Nesse aspecto, a imagem que se quer aqui construir é a do devir-onça como matilha, como imagem de pensamento que potencializa a própria literatura de Olívio Jekupé. Tomada de devir-onça, tal literatura agencia uma postura indomesticável em toda sua obra. Como se fizesse aliança e zona de fluxo com tudo o que perpassa a própria experiência do indígena no Brasil. A onça, a qual sua literatura devém, movimenta-se como experimento diabólico a todo conjunto de normas e agenciamentos maquínicos de uma tal maioridade literária, identitária, citadina.

\section{Conclusão ou por um devir-onça na literatura indígena}

A literatura indígena de Jekupé, assim experimentada, desponta como tentativa de operar uma fragmentação na organização de um projeto que homogeneíza as diferenças e resplandece uma imagem harmônica da identidade nacional. Como destacam Deleuze e Guattari (2002, p. 38), “a consciência nacional, incerta ou oprimida, passa necessariamente pela literatura". Na própria relação entre leitor e autor se promove desterritorialização. Um leitor dito "civilizado", "não indígena", experiencia a outridade indígena.

Uma voz autoral, não mais objetificada e diluída em outras formas de presença. Talvez seja esse o papel ético e de afirmação de saúde de toda literatura menor, tal como defendido por Deleuze (2011). Torna-se bastardo ou menor por toda a eternidade, pois, para existir como indígena em mundo que deslegitima social, política e culturalmente sua existência, é preciso virar onça. A literatura indígena de Olívio Jekupé, entendida enquanto menoridade literária, coloca-se enquanto deslocamento e movimento desterritorializante da própria configuração de discursos que homogeneízam os indígenas, a unidade linguística, o discurso histórico e as representações de mundo.

Talvez seja essa a experimentação mais necessária da literatura indígena contemporânea: colocar-se como fora, como escrita fugidia e nômade ao universo da representação. Escrita como devir revolucionário, como afirmação do desejo e potência de criação. Criar para existir, criar para resistir a todas as formas de morte: étnica, 
linguística, mnemônica, física. Criar para desarticular a todos os processos homogeneizadores e totalizantes que buscam uma imagem promovida como universal e promover o rompimento com um estado "tranquilo" e adormecido das coisas.

Para Mike Williams (2013), a onça-pintada representa no imaginário ameríndio um animal do poder. A evocação xamânica de seu espírito significa a evocação de todas as onças-pintadas. Embora se apresente com diversos nomes e em narrativas diferenciadas, segundo o autor, todos os xamãs trabalham com um só espírito da onçapintada. Nesse sentido, as literaturas indígenas formam um corpo diverso de forças em constante tensão, heterogêneas e flutuantes, que participam de um mesmo plano de existência. Inserem-se em um processo de criação de vida e de direitos, assim como nas lutas indígenas por sobrevivência e respeito à sua diferença enquanto povos e culturas. Não se trata somente de um movimento literário, mas uma construção em nível estético e político. Uma literatura de onças conclamada a resistir, sobreviver... como seus autores.

\section{Referências}

BARZOTTO. Leoné Astride (2012). A construção da identidade cultural por meio do texto literário pós-colonial: Brasil e Guiana. In: PINHEIRO, Alexandra Santos; BUNGART NETO, Paulo (Org.). Estudos culturais e contemporaneidade: literatura, história e memória. Dourados: Editora da UFGD. p. 81-107.

CASTRO, Eduardo Viveiros de (2007). Filiação intensiva e aliança demoníaca. Novos Estudos - CEBRAP, n. 77, p. 91-126.

CASTRO, Eduardo Viveiros de (2015). Metafísicas Canibais. São Paulo: Cosaf Naify.

CHAMORRO, Gabriela (2008). Terra madura Yvi Araguyge: fundamento da palavra guarani. Dourados: Editora da UFGD.

COSTA, Rodrigo (2015). Estrangeiros em própria terra: uma reflexão sobre filosofia na América Latina a partir da questão indígena. Problemata: Revista Internacional de Filosofia, João Pessoa, esp., p. 151-171.

DELEUZE, Gilles (2011). Crítica e clínica. Tradução de Peter Pál Pelbart. 2 ed. São Paulo: 34 .

DELEUZE, Gilles; GUATTARI, Félix (1995). Mil platôs. São Paulo: 34. v. 2.

DELEUZE, Gilles; GUATTARI, Félix (1997). Mil platôs. São Paulo: 34. v. 4. 
DELEUZE, Gilles; GUATTARI, Félix (2002). Kafka: por uma literatura menor. Tradução de Júlio Castañon Guimarães. Lisboa: Assírio \& Alvim.

DELEUZE, Gilles; GUATTARI, Félix (2012). Mil platôs. São Paulo: 34. v. 5.

DELEUZE, Gilles; PARNET, Claire (1998). Diálogos. São Paulo: Escuta.

GRAÚNA, Graça (2013). Contrapontos da literatura indígena contemporânea no Brasil. Belo Horizonte: Mazza.

JEKUPÉ, Olívio (2002b). O Saci verdadeiro. Londrina: Eduel.

JEKUPÉ, Olívio (2002c). Xerekó Arandu: a morte de Kretã. São Paulo: Peirópolis; Guarulhos: Palavra de Índio.

JEKUPÉ, Olívio (2003a). Verá: o contador de Histórias. São Paulo: Peirópolis.

JEKUPÉ, Olívio (2003b). Arandu Ymanguaré. São Paulo: Evoluir.

JEKUPÉ, Olívio (2006). Kamba'i: ajuda do Saci. São Paulo: DCL.

JEKUPÉ, Olívio (2009). Literatura escrita pelos povos indígenas: São Paulo: Scortecci.

JEKUPÉ, Olívio (2011a). Tekoa: conhecendo uma aldeia indígena. São Paulo: Global.

JEKUPÉ, Olívio (2011b). A mulher que virou urutau. São Paulo: Panda Books.

JEKUPÉ, Olívio (2012). Literatura nativa escrita por índios. Leetra Indígena, São Carlos, v. 1, n. 1, 2012.

JEKUPÉ, Olívio (2015). 500 anos de angústia. São Paulo: Scortecci.

JEKUPÉ, Olívio (Org.) (2013). As queixadas e outros contos guaranis. São Paulo: FTD.

KAFKA, Franz (1954). Journal. Tradução de Marthe Robert. Paris: Grasset.

LAPOUJADE, David (2015). Deleuze, os movimentos aberrantes. São Paulo: n-1.

LEITE, Ana Mafalda (1998). Oralidades e escritas nas literaturas africanas. Lisboa: Colibri.

LISBÔA, Paulo Victor Albertoni (2015). O escritor Jekupé e a literatura nativa. 2015. Dissertação (Mestrado em Antropologia Social) - Universidade Estadual de Campinas, Campinas.

MONTEIRO, Rui Manuel (1987). Eu e o outro: o invasor ou em poucas três linhas uma maneira de pensar o texto. In: MEDINA, Cremilda de Araújo (Org.) Sonha Mamana África. São Paulo: Epopéia. p. 308-310.

MOREIRA, Osmar (2002). Folhas venenosas do discurso. Salvador: Quarteto. 
NUNES, Benedito (2011). O animal e o primitivo: os outros de nossa cultura. Novos Cadernos NAEA, Belém, v. 14, n. 1, 2011.

ROSA, Francis Mary Soares Correia da (2016a). Tekoá: a literatura indígena e suas linhas de fuga. 2016. Dissertação (Mestrado em Crítica Cultural) Universidade do Estado da Bahia, Salvador. Disponível em: <https://goo.gl/b7waVK>. Acesso em: 10 mar. 2017.

ROSA, Francis Mary Soares Correia da (2016b). A literatura menor em Deleuze e Guattari: por uma educação menor. Educação, Santa Maria, v. 41, n. 3, p. 685-696, dez. Disponível em: <https://goo.gl/xja9BU>. Acesso em: 10 mar. 2017.

SCHØLLHAMMER, Karl Erik (2001). As práticas de uma língua menor: reflexões sobre um tema de Deleuze e Guattari. Ipotesi, Juiz de Fora, v. 5, n. 2, p. 59-70.

WEISSMANN, Dirk (2012). Le discours sur la "littérature mineure": genèse, transferts et limites d'un concept. In: ZEKRI, Caroline; RODRIGUEZ, Béatrice (Org.). La notion de "mineur" entre littérature, arts et politique. Paris: Michel Houdiard. p. 33-42.

WEISSMANN, Dirk (2013). De Kafka à la théorie postcoloniale: l'invention de la "littérature mineure". In: SCHWERTER, Stephanie; DICK, Jennifer K. (Org.). Traduire, transmettre ou trahir. Paris: Maison Des Sciences De L'homme.

WILIAMS, Mike (2013). O espírito do Xamã. Tradução de Bianca Albert. São Paulo: Alaúde.

ZOURABICHVILI, François (2009). O vocabulário de Deleuze. Tradução de André Telles. Rio de Janeiro: Relume Dumará.

Recebido em 10 de março de 2017.

Aprovado em 29 de julho de 2017.

\section{resumo/abstract/resumen}

\section{A menoridade literária em Olívio Jekupé}

Francis Mary Soares Correia da Rosa

$\mathrm{O}$ artigo investiga os mecanismos de representação política e identitária que ocorrem por meio da prática literária em comunidades indígenas brasileiras, precisamente nas obras de Olívio Jekupé. Trata também dos deslocamentos políticos que esta literatura de autoria indígena provoca no imaginário nacional e em uma perspectiva literária alicerçada no lócus enunciativo ocidental. 
Referenciando-se nos conceitos de devir, devir-animal e literatura menor de Deleuze e Guattari, busca-se apresentar como tal conjunto literário pode se experienciar como uma menoridade literária.

Palavras-chave: literatura indígena, Deleuze, Olívio Jekupé, devir-onça.

\section{The literary minority in Olívio Jekupé}

Francis Mary Soares Correia da Rosa

This paper inquires into the mechanisms of political representation and identity construction that occur through literary practice in Brazilian indigenous communities, specifically in the works of Olívio Jekupé, as well as a study of the political displacements that the literature of indigenous authors causes in the national imaginary and in a literary perspective that is based on a Western enunciative locus. Referencing Deleuze and Guattari's concepts of becoming, becoming-animal, and minor literature, the essay seeks to show how such this literary ensemble can be experienced as a literary minority.

Keywords: indigenous literature, Deleuze, Jekupé, becoming-jaguar.

\section{La minoría literaria en Olívio Jekupé}

Francis Mary Soares Correia da Rosa

El artículo investiga los mecanismos de representación política e identitária que se producen a través de la práctica literaria en las comunidades indígenas de Brasil, precisamente en las obras de Olivio Jekupé. También trata del estudio de los cambios políticos que ésta literatura de autoría indígena provoca en el imaginario nacional y en una perspectiva literaria enraizada en el locus de enunciación occidental. Haciendo referencia a los conceptos de llegar a ser, devenir-animal y literatura menor de Deleuze y Guattari, se busca presentar cómo tal conjunto literario se puede experimentar como una minoría literaria.

Palabras clave: literatura indígena, Deleuze, Jekupé, devenir onza. 